Article received on June $27^{\text {th }} 2017$

Article accepted on June $27^{\text {th }} 2017$

UDC: 78.087.684(497.11)

785.11(497.11)

\author{
Sonja Marinkovićc \\ Department of Musicology \\ Faculty of Music \\ University of Arts in Belgrade
}

\title{
THE SYMPHONY ORCHESTRA AND CHOIR OF THE FACULTY OF MUSIC IN BELGRADE ${ }^{1}$
}

\begin{abstract}
The article sheds light on the work of the Mixed Choir and Symphony Orchestra of the Faculty of Music in Belgrade, two representative ensembles that have made, over a number of decades, an invaluable contribution to the Faculty's standing in the city, nationally, as well as abroad, always taking an active part on the music scene. The aim is to show that their activities have combined pedagogical and artistic work and that they are, in an essential way, an indicator of the institution's achievements.

Key words: Academy/Faculty of Music in Belgrade, music pedagogy, Mixed Choir of the Faculty of Music, Symphony Orchestra of the Faculty of Music, Serbian music.
\end{abstract}

The Symphony Orchestra and Mixed Choir of the Academy of Music in Belgrade ${ }^{2}$ began their activities during the 1950 s, when the two ensembles were led by Vo-

\footnotetext{
* Author contact information: sonja.marinkovic@gmail.com

1 The article incorporates parts of research pursued under the auspices of Identities of Serbian Music in Global Cultural Context, a research project supported by Ministry of Education, Science and Technological Development of the Republic of Serbia (project no. 177019).

2 The Academy of Music in Belgrade was founded on 31 March 1937 as Serbia's first state school of higher education in music. In 1957, it joined the association of art academies, which were transformed into faculties in 1973, and was then renamed the Faculty of Music at the University of Arts in Belgrade.
} 
jislav Ilić (1912-1999; Ilić led the choir from 1951 to 1980) and Dušan Skovran (1923-1975; Skovran directed the orchestra from 1951 to 1975). In addition to these two mass ensembles, which included up to 320 students, there were another three chamber ensembles that were likewise important regarding the Academy's artistic activities: the Chamber Orchestra, comprising selected students from the Strings Department (1965-1980), ${ }^{3}$ women's chamber choir Collegium musicum (1971), ${ }^{4}$

3 Professor and conductor Dušan Skovran founded the chamber ensemble in 1965, whose members comprised selected students from the Strings Department. The string ensemble was renamed multiple times, appearing as the Chamber Orchestra (Ensemble) of the Academy of Music, Academic Chamber Orchestra, Jeunesses musicales Academic Chamber Orchestra, and, finally, upon Skovran's sudden passing in 1975, assumed its founder's name and appeared as Dušan Skovran Chamber Orchestra under the leadership of its new conductor, the violinist Aleksandar Pavlović. By 1975, the Orchestra had developed a dynamic concert life, touring Poland, Hungary, Belgium, Germany, France, Switzerland, Italy, and many other countries, as well as performing at the international youth orchestra festivals in Lausanne and Aberdeen. From 1975 to 1980 the Orchestra continued to build its reputation at international festivals and tours in Poland and France (April 1976), Belgium (January 1977, in Brussels and several other cities), Great Britain (August 1977, in Aberdeen and another three cities in Scotland, as well as in London), Denmark (January and February 1978 - 30 concerts), and France (February and March 1978 - 30 concerts). In 1980 the Orchestra became independent from the Faculty and was transformed into a professional ensemble, which remains active today. This journal published a piece on the ensemble on the occasion of its $30^{\text {th }}$ anniversary. Cf. Milena Pešić, "Antiche arie... le nouve musiche. 30 godina Beogradskog gudačkog orkestra Dušan Skovran", Novi zvuk, 1995, 6, 153-160.

4 The women's academic chamber orchestra Collegium musicum was founded in 1971 by Vojislav Ilić, as an "offshoot" of an earlier mixed ensemble of the same name; Ilić led the new ensemble until 1974, when it was taken over by Darinka Matić Marović. She had served as the ensemble's conductor since its founding and, working with many generations of students, achieved an excellent level of interpretation, building an ensemble that is both original and recognizable in its unique sonority, a choir that has often set the standard in choral music performance and served as a model for many. Darinka Matic Marović often enabled the best students of conducting in their generation to perform with the ensemble and thereby gain valuable experience. Thus the choir was also conducted by Zorica Mitev, who is now a conductor at the National Theatre Opera in Belgrade, and Biljana Radovanović, today a professor at the Department of Conducting at the Faculty of Music. The ensemble is currently led by Dragana Jovanović, assistant professor at the Faculty. Early on, the ensemble became a leading choir in Serbia as well as an internationally renowned performing body. Thus far, they have performed in over 3,000 concerts in Serbia and abroad - in Europe, Asia, and America (Italy, France, England, Ireland, Spain, Romania, Bulgaria, Norway, Poland, the Czech Republic, Slovakia, Austria, Germany, Portugal, Sweden, Belgium, Greece, Hungary, Mexico, Cuba, India, Pakistan, Afghanistan, Iran, Mongolia, China, Taiwan, Korea, Russia, Belarus, Turkey, Montenegro, Bosnia and Herzegovina, etc.). Also, the ensemble has had much success at prestigious international festivals, such as the Prague Spring, George Enescu festival, Moscow Festival of Sacred Music, Berlin Week, etc. At every international competition where it took part, the Collegium won top awards - first and 
and the Madrigal Choir, ${ }^{5}$ but their activities are not surveyed here in any more detail, because their scope, excellence, and intensity merit a separate article.

Vojislav Ilić joined the Academy of Music in 1951, as a professor at the Secondary School of Music, which operated as part of the Academy until 1955. That year, he succeeded Meri Dragutinović as master of the student choir, a proficient and acclaimed children's choirmaster, but relatively inexperienced in directing a student ensemble. Ilić returned to Belgrade in 1951, where his career in conducting had begun already in the 1930s, from Novi Sad, where he was reassigned following the Second World War. ${ }^{6}$ Ilić was already an established and acclaimed conductor at the National Theatre of Vojvodina ${ }^{7}$ and a professor of the state school of music when he became an editor at Radio Belgrade and then also a professor at the Academy of Music, but his teaching career in Belgrade developed only gradually, starting from a secondary school professor, then moving to the Academy as a lecturer (1954), assistant professor (1958), associate professor (1967), and full professor (1969) of choir and choral conducting. However important the performances of its ensembles may have been in terms of representing the Academy of Music, they were never regarded as the main area of that institution's field of work and were often eclipsed by its students' and teaching staff's solo performances, as well as solo instrumental and vocal pedagogy, and, especially, the Department of Composition, whose official designation at the Academy was - not merely in symbolic terms - the First Department. The gradual dynamic of Ilić's progress in the university hierarchy clearly attests to that.

Unlike Ilić, who was already well established in Serbia's musical public and had made significant artistic achievements, Dušan Skovran began his teaching career at the Academy as a very young man, right after graduation. ${ }^{8} \mathrm{At}$

special prizes (Arezzo, Llangollen, Gorizia, BBC Music Awards, Berlin, Varna). The Collegium has also appeared on various Serbian and foreign radio and TV stations. On the occasion of its $25^{\text {th }}$ anniversary, this journal published a special piece. Cf. Tatjana Marković, "Collegium musicum - 25 godina rada Akademskog ženskog hora iz Beograda", Novi zvuk, 1997, 9, 81-90. To mark its $40^{\text {th }}$ anniversary, the music journal Mokranjac published a notice by Tijana Popović Mlađenović and Milena Medić, "Akademski ženski kamerni hor Collegium musicum - leksikografska beleška povodom 50 godina od osnivanja ansambla", Mokranjac, 2010, 12, 40-43.

5 This ensemble was founded by Aleksandar Vujić, but in terms of its activities and their frequency, it could never compare to the other two chamber ensembles.

6 Cf. Katarina Stanković, Dirigent Vojislav Ilić (život i stvaralaštvo), Niš, Niški kulturni centar, 2012.

7 Between 1944 and 1951, the Serbian National Theatre in Novi Sad was called the National Theatre of Vojvodina.

8 Skovran began studying conducting with M. Vukdragović, continued studying in Leningrad, and graduated in Zagreb in 1949, under Fritz Zaun. He was further trained by Igor Markevtich at Mozarteum Salzburg, in 1955. 
the time, the teaching staff at the Department of Conducting included Mihailo Vukdragović (1900-1986; employed at the Academy between 1944 and 1972), Krešimir Baranović (1894-1975; employed 1946-1956), Predrag Milošević (1904-1988; employed 1939-1974), and Živojin Zdravković (1914-2001; employed 1949-1983); the accompanist was Tatjana Cabrić (1955-1983), but the demanding task of working with the ensembles was entrusted to the new teaching forces. That this was a justified decision was apparent already in their first performance, which Serbia's musical public at the time immediately recognized as major musical events.

The Symphony Orchestra and Choir of the Academy of Music had their first concert on 14 May $1952,{ }^{9}$ conducted by Mihailo Vukdragović and Vojislav Ilić. The following year, the Choir and Orchestra were both conducted by Vojislav Ilić and in addition to Belgrade, there was also a concert in Novi Sad - thus began the practice of presenting the work of these academic ensembles to the wider Yugoslav as well as European musical public, since their Serbian and Yugoslav tours were soon followed by tours abroad.

The ensembles cultivated a diverse concert repertoire. In à cappella performances, there was much focus on Renaissance music ${ }^{10}$ as well as works by Serbian composers, especially Stevan Mokranjac. The ensembles' vocal-instrumental performances included works by Bach (Magnificat), Buxtehude (cantatas), Vivaldi (Juditha triumphans), Handel (Israel in Egypt, Samson, parts of Mes-

\footnotetext{
9 In his summary of the activities of the Department of Conducting, written for a special edition published on the $25^{\text {th }}$ anniversary of the founding of the Academy, Vukdragovic identified a concert held on 11 June 1951 as the ensemble's inaugural performance. On that occasion, according to Vukdragović, the graduates of the Academy, led by Krešimir Baranović, performed under the name of "The Symphony Orchestra of the People's Republic of Serbia", with the following repertoire: Dramatična uvertira (Dramatic Overture) by Vasilije Mokranjac, a composition graduate; Rusalka's Aria from Dvor̆ak eponymous opera (with Anica Simurda Jelinek as the soloist), the first and second movement of Chopin's F-minor Concerto (with Vera Božić as the soloist), the second and third movement of Khachaturian's Piano Concerto (with Dušan Trbojević as the soloist), and the tone poem Beograd (Belgrade) by Dragutin Gostuški, likewise a composition graduate. Cf. Mihailo Vukdragović, "Uloga i odgovornost dirigenta", in: Stana Đurić Klajn (ed.), Dvadeset pet godina Muzičke akademije u Beogradu (1947-1962), Belgrade, Muzička akademija, 1963, 35-39. However, on 5 January 1951 the Symphony Orchestra of the People's Republic of Serbia became a state institution and, from 4 January 1952, reverted to its original name, Beogradska filharmonija (Belgrade Philharmonic).

10 This was in line with Ilić's peagogical precepts concerning the importance of securing a good vocal technique as the basis of choral music performance. They performed works by Palestrina, Monteverdi, Adriano Banchieri, Lassus, Orazio Vecchi, Luca Marenzio, and Antonio Scandello. $C f$. Katarina Stanković, op. cit., 117.
} 
siah), Pergolesi (Stabat Mater), Emmanuele d'Astorga (Stabat Mater), Mozart (Coronation Mass; Requiem), Beethoven (Mass in C Major), as well as a rich body of concertante works (Mozart, Beethoven, Weber, Mendelssohn, Chopin, Liszt, Brahms, Tchaikovsky, Lalo, and Saint-Saëns). The ensembles performed in Belgrade as well as in Novi Sad, Zagreb, and Ljubljana, and their concerts always constituted major musical events.

Especially noteworthy were concerts that the ensembles gave to mark major anniversaries of two Serbian composers - Mokranjac and Konjović. Thus Ilic marked the centenary of the birth of Mokranjac and the $50^{\text {th }}$ anniversary of his death, and the 1964 concert was reprised in Niš, Knjaževac, Zaječar, and Negotin, where the students participated in a programme celebrating the opening of Mokranjac's birth house, which had recently been renovated. Beside the customary and always popular Rukoveti (Garlands), the concert programme also included some of Mokranjac's sacred works, which was one of the first hints in Serbian post-war music that Mokranjac's sacred music was returning to the concert podium. It is precisely Vojislav Ilić who should be credited for this, a bold precedent, since following the Second World War, in line with the status of sacred music in the Soviet Union, ${ }^{11}$ Christian Orthodox sacred music entirely disappeared from concert halls. Ilić performed parts of Mokranjac's Divine Liturgy of St. John Chrysostom at a students' concert as well as with the Academic Choral Society of Zemun, where he also worked as conductor. Then, in 1966, he performed the Liturgy with Belgrade Madrigalists at the Perugia festival and the same year saw the release of the first complete recording of Mokranjac's masterpiece. Ilić made the recording with Collegium musicum, a recently established mixed students' choir of the Academy of Music. A second edition came out in 1971. The superb reception of the première abroad and glowing reviews

11 This self-censorship in our musical tradition affected not only the performance of Christian Orthodox sacred music, but also the overall status of all topics related to Orthodox Christianity. As an illustration of this, one might look at the final edition (1975) of Andreis's monumental history of music, which, following Keldysh's lead, omits all mention of Tchaikovsky's Liturgy. In the entire curriculum of the Academy of Music, in every subject, all topics related to the sacred cultural heritage of Christian Orthodox nations were either purged or totally marginalized. It is hard to understand today why the ban only applied to the Orthodox and not the Catholic or Protestant tradition and how, given the lead of European models, where the sacred tradition had become part of the secular tradition as well, there was no attempt to recognize and preserve its universal human message, despite ideological ideas concerning the "harmful effects" of religion. Vojislav Ilić was quite courageous to challenge the public in this way, faced with ideological pressures and the shadow that hung over his entire career, due to his closeness to the Faculty of Theology and the Orthodox Church. That courage was inspired by his huge love for a heritage that he knew and understood in an essential way. 
from Italy helped enable the first integral concert performance of the liturgies of Mokranjac and Tajčević in Belgrade in 1967. On that occasion, the Madrigalists were led by Dušan Miladinović.

The best performances of the Choir and Symphony Orchestra at this time were their renderings of works by Handel: the oratorios Israel in Egypt ${ }^{12}$ in 1963 and Samson in 1971. ${ }^{13}$ These were the first performances of these monumental works in Belgrade and, in the context of Serbia's musical life at the time, magnificent musical events, because a Handel oratorio performance, since his own day, has always constituted a special and extraordinary musical spectacle in every centre of music. It is therefore hardly surprising that the ensembles performed Israel in Egypt not only at Belgrade's Kolarac Endowment Hall, but also in Novi Sad, Zagreb, and Ljubljana. The reviews were superb, stressing the qualities of the ensemble - its homogeneous sound, rhythmic stability, carefully constructed dynamics, finely chiselled polyphonic structures, the conductor's skill and diligence, and the ensemble's discipline and high degree of artistic accomplishment, which would not shame even a professional choir and orchestra. ${ }^{14}$ Ilić's farewell concert with the ensembles of the Academy of Music was likewise an important musical event: a performance of the complex score of Samson. The mounting of such large-scale projects was possible because the Academy of Music accepted a large number of students at the time,,$^{15}$

12 The soloists included Stevka Babović Čalovska, soprano; Julijana Anastasijević, alto; and Radovan Popović, tenor.

13 The soloists were Miska Šćepanović, soprano; Aleksandra Ivanović, alto; Sead Buljubašić, tenor; Dušan Janković, baritone; and Miomir Nikolić, bass; the continuo was played by Ljubica Grujić. The programme also included parts of Messiah, but these two oratorios are singled out as projects involving integral performances of works by Handel.

14 Cf. Katarina Stanković, op. cit., 120-124.

15 Whereas in 1951 only 74 students were enrolled, in the early 1970 s the number of new students rose to as many as 199 , which also meant a significant rise in the overall number of students: in 1962-63 there was a total of 446, whereas in 1966-67 that number rose to 542 . During the 1970s the number of new students varied from 85 (1978) to 173 (1981). Cf. Roksanda Pejović (ed.), 50 godina Fakulteta muzičke umetnosti (Muzičke akademije), Belgrade, FMU, 1988, 178. In 1959, by a ruling of the Ministry, all secondary-school graduates could automatically enrol at the Academy, without sitting for an entrance exam. That, however, failed to generate a significant increase in the number of students enrolled; on the contrary, in those years, the number of new students was at its minimum: in the academic year of 195859 , only 59 enrolled; in 1959-60,60; and in 1960-61, 66. Also, 1959 saw the introduction of third-level curricula, but this was discontinued in 1975, following explicit demands from the students. Incidentally, 1959 was also important because that year the government decided that all secondary music school diplomas issued in the interwar period would be recognized as equivalent to university degrees, whereby these de facto conservatory-level institutions 
but that does not mean that working with massive ensembles was for that reason any easier - on the contrary.

Dušan Skovran's performances with the Academy's orchestra (1951-1975) were typically designed to highlight the soloists, ${ }^{16}$ often including only individual parts of larger, cyclical works, in order to enable a larger number of outstanding students to perform with the orchestra. However, the reviews from those years also highlight certain difficulties in the functioning of the Academy's orchestra. A number of students were employed and could attend the rehearsals regularly, which inevitably affected the quality and frequency of the performances. Also, there was no equal representation of students in the winds (and even strings) and this did not change until the late 1970s or even early ' $80 \mathrm{~s} .{ }^{17}$ For concert performances, the student forces of the orchestra were routinely "reinforced" by their professors; likewise, alumni or colleagues from professional orchestras were often enlisted as "helpers", in order to realize certain projects. To deal with the shortage of strings, which was evident even in Serbia's professional orchestras, between 1975-76 and 1987-88, the students of the Strings Department, starting in their third year of studies, were divided in two groups - one comprising future concert performers and the other teachers and orchestral performers. Also, 1973-74 saw the founding of the School for Musical Talents in Ćuprija, a boarding school for young string players that was meant to enable them, using a special integrated 10-year curriculum of primary

were recognized as such. Before that decision, in the eyes of the state, Stana Đuric Klajn, for instance, a pioneer of Serbian musicology, officially only had a secondary-school diploma. Cf. Sonja Marinković, "Istorijat Fakulteta muzičke umetnosti: razvoj studijskih programa", in: Vesna Mikić and Tijana Popović Mlađenović (eds.), Tematski potencijali leksikografskih jedinica o muzičkih institucijama, Belgrade, Katedra za muzikologiju Fakulteta muzičke umetnosti, 2009, 61-70.

16 Especially noteworthy were performances by the violinist Dragutin Bogosavljević, pianist Vera Miletić, singer Julijana Anastasijević, violinists Aleksandar Stajić and Jovan Kolundžija, and pianist Ljubinka Kostović, among others. Cf. Roksanda Pejović, op. cit., 52-53. 17 In fact, only the clarinet class always had a steady supply of students. Starting from the academic year of 1953-54, the number of newly enrolled students was between one and five. The first flute graduates came out only in 1957, while there were no graduates in 1960-61, 1964-65, and 1967-68; the first graduates of oboe came out only in 1962-63; the first bassoonists graduated in 1953-54, but then after 1965-66 there were no more graduates from that class for the next four years. The brass department experienced a similar situation: after 1951 , the first horn graduate came out in 1965-66, the first trumpet graduate in 1964-65, the first trombone graduate in 1963-64, and there were no graduate tuba players. There was no double-bass class until the first graduate came out in 1969-70, no violoncello class until 1959-60, and no viola class until 1960-61. 
and secondary education in music and general subjects, to enrol at the Faculty immediately upon graduating.

There was another generation shift at the Department of Conducting in the early 1970s, which saw the appointment of Darinka Matic Marovic (19712002), Stanko Šepić (1974-2008), Mladen Jagušt (1975-1978), and Jovan Šajinović (1924-2004; Śajinović joined the Faculty of Music in 1976, when he was appointed full professor and chair of the Department of Conducting). Apart from teaching conducting as the main subject in undergraduate and graduate studies, led by these professors, equally important were their activities concerning the Faculty's large ensembles - the Mixed Choir, which was led by Darinka Matic Marović, and the Symphony Orchestra, led by Stanko Šepić. ${ }^{18}$

In the Faculty's golden jubilee year, according to the reviews, the student orchestra demonstrated its ability to follow the conductor's intentions and achieve genuinely accomplished interpretations. Led by Professor Stanko Šepić, the orchestra received top marks at the 1987 European Music Festival for Young People in Neerpelt, Belgium. The programme included Beethoven's Fifth Symphony, Scherzo in F by Petar Obradović, and Liszt's Preludes. Between 1 and 18 March 1990, the 59-strong orchestra, led by Šepić, went on a tour of 10 cities in France, organized by Jeunesse musicale de France, including Paris, where they performed at the Grand Auditorium of UNESCO on 4 March 1990. ${ }^{19}$ The repertoire was suggested by the French side. The evening concerts featured the Overture from Mozart's Magic Flute and his C-major Piano Concerto (KV 467) with Paul Echeverri as the soloist, Beethoven's Fifth Symphony, and "Grlica" from Stevan Hristić's ballet The Legend of Ohrid. The school performances featured a somewhat different programme. Following the first movement of Mozart's G-minor Symphony, the orchestra played fragments from Beethoven's Egmont, then Dvořak's Slavonic Dance in E minor; this was followed by a 30 -second percussion improvisation, Mozart's Divertissmento in D major (the beginning of the first movement), the fourth movement of Beethoven's Fifth Symphony, and "Grlica". The final, also extremely successful foreign tour led by Stanko Sepić happened in 2007, in Banja Luka (Bosnia and Herzegovina), Pula (Croatia), and Ljubljana (Slovenia). The programme included Lirska poema (Lyric Poem) by

18 Although in terms of organization Šepić was officially designated as the professor of orchestra and Matić Marović as the professor of choir, in practice, Matić Marović appeared as the artistic leader in all vocal-instrumental and symphonic projects.

19 The itinerary was the following: Lille - 5 March; Dink - 6 March; Saint-Malo - 8 March; Vannes - 9 March; Châteaudun - 10 March; Flers - 11 March; Bourg-en-Bresse - 13 March; Sète - 15 March; Béziers - 16 March; and Agde - 17 March. In total, they played 25 concerts. 
Vasilije Mokranjac, Brahms's Second Piano Concerto (the soloist was Bojan Marjanović), and Tchaikovsky's Fifth Symphony. ${ }^{20}$ The tour was organized as an exchange project between the Academy of Music in Ljubljana and the Faculty of Music in Belgrade; while the performances in Banja Luka and Pula were sort of "complementary" to the main event, the performance at the Grand Hall of the Slovenian Philharmonic as part of their regular concert season (the $11^{\text {th }}$ concert, held on 23 December 2007). Our young musicians were warmly received and especially effective was their interpretation of Tchaikovsky's symphony, which they performed with ample precision, excellent solos, especially the horn and the clarinet, with much inspiration, virtuosity, and energy, as befits youth. ${ }^{21}$

The ensembles' hugely successful showings in national and international competitions and tours, their rich and amply noted concert activities resulted from working strictly according to a carefully conceived plan and from choosing the repertoire according to stylistic criteria, bearing in mind the need to enable young people to master a wide range of styles, from baroque, classical, romantic, to $20^{\text {th }}$-century music (Debussy, Ravel, Prokofiev). The ensemble thereby duly presented the fullness of their performance potential, whose demands and quality equalled and, in terms of accomplishment, according to the critics, often surpassed professional ensembles. Concert evenings dedicated to Bach, Handel, Mozart, Beethoven, Rossini, Wagner, Brahms, Dvořak, Debussy, Prokofiev, as well as performances of important works by Serbian authors (Stevan Hristić, Vasilije Mokranjac) constituted major artistic events each season and the ensembles were thus given an opportunity to perform at Serbia's biggest festivals of music - Bemus, Nimus, and others.

The tradition of organizing vocal-instrumental concerts was likewise continued, and especially successful were performances of Carl Orff's Carmina burana (also performed on the occasion of the Faculty's $65^{\text {th }}$ anniversary) ${ }^{22}$ and

20 Šepić's website at http://stankosepic.com contains links to the following YouTube videos: an excerpt from Wagner's Tristan und Isolde, the first movement of Tchaikovsky's Fifth Symphony, the first movement of Sergei Rachmaninoff's Second Piano Concerto, and the following movements from Sergei Prokofiev's Romeo and Juliet: "Montagues and Capulets", "Juliet as a Young Girl", and "At Juliet's Bedside".

21 There was an interesting detail concerning the programme notes for the concerts in Ljubljana and Belgrade. If one compares them, one may note that the front page of the Ljubljana programme notes also features the name of Bojan Marjanović's mentor, assistant professor Vladimir Cvijić. This suggests a good academic practice, evidently followed even in subscription performances of student ensembles.

22 Like many other projects, this project, too, was realized by several Belgrade ensembles working together. The concert featured the Choir and Symphony Orchestra of the Faculty of Music, the choir "Obilić" of the Academic Art and Cultural Society "Branko Krsmanović", 
Mozart's Requiem, Bach's Magnificat, and Bernstein's Chichester Psalms. Projects like these were typically led by Darinka Matić Marović, who also conducted the Mixed Choir's à cappella concerts. This tradition, too, was maintained regularly. The Choir's repertoire included Vezilja slobode (The Girl Embroidering Freedom), a cantata by Mihailo Vukdragović, Četiri duhovna stiha (Four Sacred Verses) by Marko Tajčević, Simfonijski epitaf (Symphonic Epitaph) by Radomir Petrović, Hristić's Opelo (Orthodox Requiem), and other works. Also, the Choir took part in vocal-instrumental projects organized by the Belgrade Philharmonic. Darinka Matić Marović thus prepared the Choir for a joint performance of Pergolesi's Stabat Mater with the Belgrade Philharmonic Orchestra, led by Angel Šurev (1987). Providing her students with a huge body of knowledge, cultivating in them a highly professional approach to work as well as ethics and exalted human ideals, Matić Marović made a significant contribution to the development of professional standards in the domain of Serbian art music.

A special domain of the Choir and Symphony Orchestra's activities has included the realization of shared projects with students from the region. The students of the Faculty of Music have also sung and still sing as soloists and choristers with other Serbian and foreign choirs and, since September 1989, with the World Youth Choir as well. Similarly, thanks to regular annual competitions, the Faculty's students have the opportunity to collaborate with major European youth performing bodies and perform across the world. ${ }^{23}$ In 2006, with assistance from the Swedish International Development Cooperation Agency (SIDA), the $250^{\text {th }}$ anniversary of the birth of Mozart was marked with a performance of his Requiem as part of Dani Vlade S. Miloševića (Vlada S. Milošević's Days) in Banja Luka and Brčko, Bosnia and Herzegovina. The event saw joint performances of the choirs and orchestras of the faculties and academies of music from Belgrade, Banja Luka, Kragujevac (Serbia), Cetinje (Montenegro), Sarajevo, East Sarajevo, and Bijeljina (Bosnia ad Herzegovina). On 13 December 2010, Belgrade's Kolarac Endowment hosted a performance of the symphony orchestras of the Faculty of Music from Belgrade, the Academy of Music from Sarajevo, and the Academy of Art from Banja Luka, conducted by Branka Radošević from Banja Luka; the title of the concert was An Evening of Duets, fea-

featuring Snežana Savičić and Nikola Mijailović as soloists. Biljana Radovanović played the piano, while the choirs were prepared by Biljana Radovanović and Nebojša Stepić, and the orchestra by Vesna Šouc. The concert was held at the Kolarac Endowment on 27 December 2002.

23 The Faculty hosts Serbia's national auditions for the Gustav Mahler Jugendorchester, as well as for Bayreuth summer courses in orchestral and chamber music making. Also, its students have the opportunity to sing with the Bayreuther Festspiele festival choir. 
turing works by Konstantin Babić, Camille Saint-Saëns, Modest Mussorgsky, and Francis Poulenc (the soloists were students Dejan Trkulja, clarinet; Sonja Vojvodić, violin; Nenad Trbojević, flute; Sonja Bobrek, piano; and two professors, Vladimir Cvijić and Dinko Blagojević, who soloed in Poulenc's Concerto for Two Pianos and Orchestra). In 2011, SIDA sponsored another concert tour of the Faculty of Music Symphony Orchestra. ${ }^{24}$

Unfortunately, only a fraction of all these activities has been made available to the general public on permanent recordings, although recorded materials do exist. In this regard, especially noteworthy is the recording titled 40 godina Fakulteta muzicke umetnosti (1937-1977) (40 Years of the Faculty of Music, 1937-1977), featuring students' interpretations of various pieces. The B side of this recording is dedicated to Serbian choral music, with works by Vojislav Ilić, Radomir Petrović, Konstantin Babić, Dragutin Gostuški, and Dušan Kostić, performed by Collegium Musicum Women's Academic Choir led by Darinka Matić Marović.

Conductors belonging to a younger generation (at the time) have also been engaged to work with the Orchestra and Choir - Biljana Radovanović (from 1992), Vesna Šouc (from 1993), Aleksandar Vujić (1974-2013), and Dragana Jovanović (from 2010), but the ensembles have been led with equal success by foreign guests as well (Max Frei, Hans-Joachim Lustig, János Fürst ${ }^{25}$ ), giving rise to a number of interesting projects.

In the long run, the frequent changes of the ensembles' artistic leadership had an adverse effect on them and their work gained a new momentum only in 2005 , with the appointment of Bojan Suđić as professor of conducting and artistic leader of the Symphony Orchestra and Biljana Radovanović and then also Dragana Jovanović as leaders of the Mixed Choir. After 2012, with one exception, they assumed the artistic leadership of the Choir and Symphony Orchestra in full. ${ }^{26}$ In addition, the ensembles have also performed under the leadership

24 The Orchestra performed at the Belgrade Philharmonic Hall on 30 November 2011, in Banja Luka's Banski dvor on 5 December 2011, and the Hall of the Slovenian Philharmonic on 7 December 2011. Under the leadership of Aleksandar Vujić, the Orchestra performed Brahms's D-minor Piano Concerto (the soloist was Ljubica Stojanović) and Beethoven's Fourth Symphony.

25 This was part of the $34^{\text {th }}$ Bemus festival. János Fürst, professor at the Paris Conservatoire and a well known French conductor of Hungarian origin, performed with the Symphony Orchestra of the Faculty of Music the Lyric Poem by Vasilije Mokranjac, Ravel's G-major Piano Concerto (the soloist was Vladimir Milošević, at the time a student of Professor Nevena Popović), and Shostakovich's Fifth Symphony. The concert marked a jubilee, the $65^{\text {th }}$ anniversary of the Academy of Music in Belgrade.

26 Vesna Šouc conducted a concert on 3 December 2014, featuring a diverse programme. 
of teaching assistants and students of conducting at the Faculty, including Ivan Marković, Olga Milićević, Ana Ćosović, and Bojan Kljajić, among other.

Concerning the projects led by Biljana Radovanović, especially noteworthy are her interpretations of several complex sacred works, which pose serious challenges even to professional ensembles: Stevan Hristić's Opelo (2010), Pavel Chesnokov's Liturgy of Saint John Chrysostom, Rachmaninoff's All-night Vigil (abridged, 2011), Tchaikovsky's Liturgy of Saint John Chrysostom (2002, 2015), and Ariel Ramírez's Misa Criolla (2015). Also, the Choir took part in the commemoration of poet Miklós Radnóti's centenary in 2009. On that occasion the Choir performed Razglednice (Postcards), a work by Serbian contemporary composer Milica Paranosić. ${ }^{27}$ The piece was first presented at the Atrium of the National Museum (26 April 2010), which was followed by performances in Bor (Serbia) and Budapest (30 April 2010). Marking the centenary of Mokranjac's death in 2014, the Choir performed a rather demanding programme comprising a selection of sacred and secular works. ${ }^{28}$ The ensembles also marked Josip Slavenski's jubilee by performing his Simfonija Orijenta (Symphony of the Orient; 2013) and, the same evening, Marko Tajčević's Četiri duhovna stiha. The Faculty's ensembles have often programmed works by Konstantin Babić and one concert, organized as part of the book launch of Babić's autobiography, was

The soloists were Hana Paraušić on the harp (Joaquín Rodrigo, Concierto de Aranjuez), Evgenija Jeremić and Ana Stanković, both sopranos (arias from operas by Leoncavallo and Puccini), and Vladan Luković, trumpet (Haydn's Trumpet Concerto); the programme also included Ruzmarin (Rosemary), a symphonic suite by Konstantin Babić. That year, the ensembles gave a whole series of concerts, performing under nearly all the members of the Department: Dragana Jovanović on 20 January (choral works by Ernst Toch, Thomas Jennefelt, Toma Prošev, and Lorenzo Donati; the venue was Teatar 78); Biljana Radovanović (with Dragana Jovanović and Bojan Kljajić) on 7 April, to mark the centenary of Mokranjac's death; Bojan Suđić on 10 April (Chopin's Piano Concerto No. 1 with Vuk Božilović and Mussorgsky's Pictures at an Exhibition); Dragana Jovanović and the Choir at Bemus on 22 October (Komitske pesme / Outlaws' Songs by Marko Tajčević); and Vesna Šouc on 3 December, at the concert mentioned above.

27 Razglednice is a work written for choir, soloists, narrator, and chamber ensemble. The soloists were Mina Kovač, soprano/Angel; Marija Mitić, soprano: Ana Radovanović, mezzo-soprano; Dejan Ljutovac, tenor; Danilo Stošić, tenor; Vuk Zekić, baritone; Ana Martinović as the mourner; Jovana Karnić and Ladislav Mezei, cellists, and Srđan Palačković on the percussion.

28 Beside Biljana Radovanović, Dragana Jovanović and Bojan Kljajić also conducted that evening, and the soloists included Evgenija Jeremić, soprano; Nenad Čiča, tenor; Ivan Dajić, bass; and Mladen Stefanović, piano. The Choir sang Mokranjac's Liturgy (excerpts), Srpske narodne pesme (prva smeša) (Serbian Folk Songs, First Medley), and Rukoveti (Garlands) Nos. 2, 3, 7, 10, and 14. The concert was held at Kolarac on 7 April 2014. 
entirely dedicated to his oeuvre. ${ }^{29}$ Biljana Radovanović has likewise performed with the Symphony Orchestra of the Faculty of Music. She conducted the orchestra at a concert held at Kolarac on 26 December 2006. The programme featured works by Schubert, Tchaikovsky, Dámaso Pérez Prado, and Rossini.

Dragana Jovanović's performances with the Mixed Choir of the Faculty of Music have featured a wide range of works in terms of style, from baroque (Vivaldi's Gloria, 2010) to Serbian sacred music (Hristić's Opelo, performed at Budai Vigadó in Budapest on 18 April 2012). Jovanović has also realized a number of interesting projects presenting previously unfamiliar authors to Serbian audiences. She thus conducted a performance of Valerije Kikt's Svetlost tihih zvezda (Light from Quiet Stars) at the opening of the $10^{\text {th }}$ International Harp Festival, with the Mixed Choir of the Faculty of Music and an ensemble comprising 12 harps, with Aneta Ilić and Dejan Maksimović as soloists. ${ }^{30}$ More recently, a particularly successful project of this type was a joint performance of the Faculty's ensembles with the Faculty of Drama, which revived, after a long hiatus, the Summer Stage in Topčider, an old park on the south side of Belgrade. The event saw a staging of David Fanshawe's African Sanctus, a multimedia spectacle for mixed and women's choir, vocal and instrumental soloists, and tape. ${ }^{31}$ Jova-

29 The book launch was a heterogeneous type of event (the title of Babić's book is Dixit et salvavi anima mea). It included talks by Dušanka Jelenković Vidović, a musicologist, and Svetislav Božić, a composer; a short film; and the musical segment, which was conducted by Biljana Radovanović, assisted by Ivan Marković, featuring the Choir (Žablja idila / Frog's Idyll and Tri madrigala / Three Madrigals); Trio Anima (Sećanja / Memories, Vrana i Orao / The Crow and the Eagle, and Prolog, predlog i epilog / Prologue, Proposition, and Epilogue); Vladimir Gagić, clarinet (Binom / Binomial); Mina Gligorić, soprano (Šašava pesma / Silly Song, Tango bugi bel, with the String Orchestra of the Faculty of Music, conducted by Ivan Marković); Nataša Mitrović, piano (Raspletum); and Edit Makedonska, violin (Melankolija / Melancholia). The concert was held at Kolarac on 23 December 2014.

30 The concert was held on 2 April 2011 and a permanent recording of the event was produced by the Radio Television of Serbia.

31 African Sanctus, a multimedia spectacle by David Fanshawe for mixed and women's choir, vocal and instrumental soloists and tape, performed by the Mixed Choir of the Faculty of Music; Collegium Musicum Academic Choir; Aleksandra Jovanović, soprano; Dora Barsos, gospel soprano; Mladen Stefanović, pianist; students from the Percussion Department (Nevena Đorđević, Nikola Veličković, Strahinja Božić, Dimitrije Mojsijević, and Milan Milić) and Jazz Department of the Faculty of Music (Dragan Hajnrih, electric guitar and Aleksandar Petrović, bass guitar); Mlađan Matavulj and Prvoslav Živanović, sound designers (Faculty of Drama); Stefan Čeganjac, playback operator (student of composition); Milan Kolarević, lighting designer; and Nemanja Stamatović and Petar Dimić, actors. The conductor was assisted by Bojan Kljajić and the director was Branislava Stefanović. The event was held at the Summer Stage in Topčider on 26 May 2016. 
nović also demonstrated her penchant for exploration with a concert series titled Iz riznice biblioteke FMU (From the Treasury of the Faculty of Music Library), featuring sacred works by Marko Tajčević and Miloje Milojević.

Right from the outset of his tenure, Bojan Suđić initiated changes in the work of the Orchestra, focusing on the realization of two artistic projects every year, without, however, discontinuing its other engagements and activities, above all in relation to the teaching of conducting, enabling students to work with their colleagues and even use the Orchestra to sit for their annual exams. ${ }^{32}$ The teaching of Orchestral Parts was primarily made to serve the purpose of preparing individual groups for the audition where the best students are selected to perform in the concert. The previous practice, whereby the subject was taught by professors of conducting, was gradually replaced by hiring special teachers to work with individual instrumental groups, professors with performing experience in that domain that they could really communicate to the students. These include top artists, such as violinist Srđan Grujić and oboist Miloš Vasiljević; the subject is now taught by professors of conducting only to a limited degree, only certain instruments, and instruction is now organized in groups. ${ }^{33}$ This favours a more efficient type of work and brings the Orchestra's concert preparations closer to professional standards, where one only has a limited amount of time to prepare for the concert and every individual must also practise by him/herself, like a professional. At the beginning of Suđić's tenure, there was a desire to enable each member of the Conducting Department to perform with the ensembles, but this practice was gradually abandoned.

The new organization of work at the Orchestra has enabled major strides in terms of programming, as well as the attainment of an invariably high level of artistic accomplishment in the Orchestra's performances, which are now eagerly awaited every year as the season's main event, and for good reason. This was the prevailing assessment of Suđić's performances during the first several years of his tenure - Beethoven's Fifth Symphony, Mozart's Requiem, Schubert's Unfinished, and other works. In April 2007, marking a shared jubilee, the $70^{\text {th }}$ anniversary of the founding of the Faculty of Music and the Symphony Orchestra of the Serbian Broadcasting Corporation, as well as 100 years since the establishment of the University of Belgrade, in collaboration with a number of amateur choirs

32 Likewise interesting was the initiative to have some of the Orchestra perform in the staging of Gluck's Orfeo ed Euridice at the Museum of Yugoslav History, conducted by Premil Petrović, at the 2006 Bemus. Since this had not been defined as part of the teaching process, it was necessary to hire musicians from professional orchestras as well, but students nonetheless constituted the basis of that ensemble.

33 Each semester, the subject is assigned to one of the conducting professors. 
from Belgrade, Suđić staged a monumental project at Belgrade's Sava Centre: Berlioz's Requiem (26 April, with Joseph Wolverton as the tenor soloist). This was followed by new performing challenges and tackling the most complex works of symphonic and vocal-symphonic music: Mahler's First (7 April 2015) and Eighth Symphony ${ }^{34}$ (26 May 2012), Shostakovich's First (10 December 2008) and Fifth Symphony (13 April 2016), Verdi's Requiem (5 December 2013), ${ }^{35}$ Rimsky-Korsakov's Scheherazade (3 December 2013), Mussorgsky/ Ravel's Pictures at an Exhibition (10 April 2014), Beethoven's Third Symphony (12 December 2012), Sibelius's Second Symphony, Berlioz's Symphonie fantastique (2 December 2015), and other works. As for Serbian composers, Suđić performed works by Petar Konjović (two movements from his Triptihon / Triptychon, on 22 December 2005), Vasilije Mokranjac (Dramatična uvertira, on 27 April 2010), and premièred a work by Vladimir Trmčić, Zeleno sunce Janusa (The Green Sun of Janus, on 7 April 2013). Traditionally, the Orchestra continued performing with the best students of the Faculty as soloists. ${ }^{36}$

Working with a top class conductor has proved highly stimulating and beneficial for the students. The skill, knowledge, dedication, and energy with which the Faculty of Music has realized its projects is the best illustration of the accomplishment of its teaching activities and confirmation that its young musicians are fully prepared for their future engagements in professional ensembles. However, during the past several years, only a small number of graduates have been able to join professional orchestras in Serbia immediately upon graduating and many of them have left and developed highly successful career in ensembles throughout the world. That is why a recent initiative, made on the basis of an

34 With the Choir and Symphony Orchestra of the Serbian Broadcasting Corporation; the soloists were Snežana Savičić Sekulić, soprano; Ivana Petrović, soprano; Aneta Ilić, soprano; Jenela Končar, mezzo-soprano; Jelena Bodražić, alto; Yonghoon Lee, tenor; Vasa Stajić, baritone; and Nebojša Babić, bass.

35 The soloists were Jasmina Tumbetaš Petrović, soprano; Nataša Jović Trivić, mezzo-soprano; Nikola Kitanovski, tenor; and Dragoljub Bajić, bass.

36 Every year, one concert is organized in collaboration with one or more of the Faculty's performance departments. This often involves the Department of Singing (Mina Kovač, Marija Mitić, Ana Radovanović, Dejan Lutovac, Danilo Stošić, Vuk Zekić, Jelena Banković, Iva Profaca, Maja Mijatović, Nenad Čiča, Olivera Tičević, Jovana Čurović, Tamara Grubin, Ana Kovačević, Milica Jovičić, Gorana Radenović, Sava Vemić, Dragutim Matić, Evgenija Jeremić, Ivan Dajić, Ana Stanković, Mina Gligorić, Aleksandra Stanković, Aleksandra Jovanović), the Multiple Instruments Department (Ivan Marjanović, marimba; Milan Popović, harpsichord; Mina Marinković and Hana Paraušić, harp), as well as students of piano (Tea Anrijić, Bojan Marjanović, Vuk Božilović, Mina Ristić, Marija Golubović, Nenad Živojinović), violin (Mladen Drenić), trumpet (Vlada Luković), bassoon (Mihajlo Radivojević), and violoncello (Jelena Ilić). 
agreement between the governments of Serbia and Italy, in collaboration with the Ministry of Education, Universities, and Research of the Italian Republic and Giuseppe Tartini Conservatory in Trieste, is so important: to establish, under the leadership of Maestro Bojan Suđić, a joint ensemble of the Faculty of Music and the Academy of Art in Novi Sad. The idea was inspired by Italian experiences gained from the national Symphony Orchestra of Italian Conservatories, which performed a series of concerts entitled Notes of Friendship in Belgrade, Novi Sad, and Trieste, in December 2015. ${ }^{37}$ This ensemble brings together the best students from each conservatory in Italy, the students receive stipends for their work, and unlike many European ensembles, who come together only for one or two major tours every year, ${ }^{38}$ this orchestra remains active throughout the year and represents Italy on its foreign tours. The repertoire of such a performing body is constructed carefully, striving for a balance between teaching needs and audience expectations. Serbia could likewise use a similar performing body and, in a sort of anticipation of such an ensemble, a planned tour brought together the best students of the Faculty of Music in Belgrade and the Academy of Art in Novi Sad. Even though the tour was organized right at the beginning of the academic year, which meant that the rehearsals had to take place in the heat of the exam season, the response and discipline of the selected students were a clear indication just how badly they missed performing in public and how attractive they found the idea of collaborating with students from another institution and thus gaining international concert experience.

The ensemble, named "Simfonijski orkestar BENSO", performed in Novi Sad (at the Synagogue, on 5 October 2016), Belgrade (Kolarac, 6 October), Trieste (Sala de Banfield-Tripcovich, 8 October), and Milan (La Sala Verdi of the Conservatorio Giuseppe Verdi, 9 October), featuring the excellent young Italian clarinettist Daniel Roscia as the soloist. ${ }^{39}$ The programme was well thought out, featuring demanding and "flashy" pieces, ${ }^{40}$ with an unmistakeable message -

37 The orchestra, comprising students from some 60 institutions, performed works by Nino Rota and Ottorino Respighi, as well as Elgar's Cello Concerto featuring the young Serbian cellist Irena Josifovska. The conductor was Maestro Giuseppe Grazioli.

38 The student orchestra at Bayreuth is active only during the festival, Gustav Mahler Jugendorchester organizes only two major tours every year, and most other corresponding performing bodies follow similar schedules.

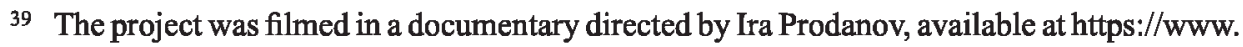
youtube.com/watch? $\mathrm{v}=0 \mathrm{Vs5F71LIfc}$, and the concert in Belgrade was broadcast on Channel 2 of Serbia's state television, available at https://www.youtube.com/watch? $\mathrm{v}=2 \mathrm{mqba} 7 \mathrm{GQh} g I$.

40 Tchaikovsky, Capriccio Italien; Rossini, Introduzione, tema e variazioni for clarinet and orchestra in B-flat major; Rimsky-Korsakov, Fantasy on Serbian Themes, Op. 6; Stevan Hristić, excerpts from his ballet Ohridska legenda; and Tchaikovsky, Marche slave. 
presenting representative works of Italian and Serbian music, as well as works from the rich treasury of Slavic music inspired by the beauties of Italy and musical folklore of Serbia. Having prepared in entirely professional conditions (not merely in terms of the number of rehearsals, led by the experienced and skilful hand of their conductor, the young symphonists achieved a perfect blend and impressive mastery and persuasion of interpretation in a very short time, allowing the advantages of youth - fervour, inspiration, and energy - to impress their audiences, who greeted them with ovations wherever they performed. It goes without saying that each member of the orchestra was entirely secure in terms of technique and intonation, because they showed much more than that, generating a homogeneous sound, noble and blended colour of the string corps, while the soloists' skill, clear musical logic of every phrase, and virtuosity impressed everyone. Above all, they performed as a collective, thus legitimizing their right to work in adequate conditions, not only when funded by the Government of Italy.

Although the concert activities of the ensembles of the Faculty of Music in Belgrade are somewhat younger than the institution itself, over the decades they have attained a continuity of performance and proved themselves as an important segment of Serbia's musical life. The purpose of this overview was to highlight the constants in the activities of the Faculty's ensembles, as well as potentials for improvement and mastering new forms of presenting the results of their work.

\section{References}

[Đurić Klajn, Stana], Dvadeset pet godina Muzičke akademije u Beogradu (1947-1962), Belgrade, [Muzička akademija], 1963.

Marinković, Sonja, "Istorijat Fakulteta uzičke umetnosti: razvoj studijskih programa", in: Vesna Mikić and Tijana Popović Mlađenović, Tematski potencijali leksikografskih jedinica o muzičkim institucijama, Belgrade, Katedra za muzikolgiju Fakulteta muzičke umetnosti, 2009, 61-70.

Marković, Tatjana, "Collegium musicum -25 godina rada Akademskog ženskog hora iz Beograda", Novi zvuk, 1997, 9, 81-90.

[Pejović, Roksanda (ed.)], 50 godina Fakulteta muzičke umetnosti (Muzičke akademije), Belgrade, FMU, 1988.

Pešić, Milena, "Antiche arie... le nuove musiche. 30 godina Beogradskog gudačkog orkestra Dušan Skovran", Novi zvuk, 1995, 6, 153-160.

Popović Mlađenović, Tijana and Milena Medić, “Akademski ženski kamerni hor Collegium musicum - leksikografska beleška povodom 40 godina od osnivanja ansambla", Mokranjac, 2010, 12, 40-43.

Stanković, Katarina, Dirigent Vojislav Ilić (život $i$ stvaralaštvo), Nišs, Niški kulturni centar, 2012. 